Jurnal Keperawatan Silampari

Volume 4, Nomor 1, Desember 2020

e-ISSN: 2581-1975

p-ISSN: 2597-7482

DOI: https://doi.org/10.31539/jks.v4i1.1772

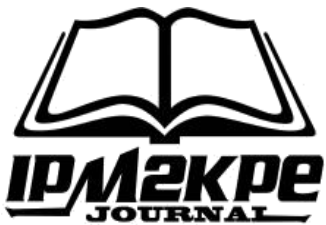

\title{
HIPNOSIS LIMA JARI KOMBINASI INSTRUMEN MUSIK POP MENURUNKAN KECEMASAN WANITA PRODUKTIF DIMASA PANDEMI COVID-19
}

\author{
Putu Agus Ariana ${ }^{1}$, Putu Indah Sintya Dewi ${ }^{2}$, I Dewa Ayu Rismayanti ${ }^{3}$ \\ Sekolah Tinggi Ilmu Kesehatan Buleleng ${ }^{1,2,3}$ \\ putuagusariana234@gmail.com ${ }^{1}$
}

\begin{abstract}
ABSTRAK
Penelitian ini bertujuan untuk mengetahui perbedaan tingkat kecemasan pada wanita produktif dimasa pandemi COVID-19 sebelum dan setelah diberikan hipnosis lima jari kombinasi instrumen musik pop di Desa Bengkala, Kabupaten Buleleng Bali. Metode penelitian ini adalah penelitian kuantitatif dengan rancangan pra eksperimental, one grup pre-post test design. Hasil analisis univariat dari 20 responden sebelum diberikan intervensi, rata-rata kecemasan yang diperoleh adalah 20,85 dengan skor kecemasan terendah adalah 15 atau kecemasan ringan dan nilai tertinggi adalah 27 atau kecemasan sedang. Setelah diberikan intervensi, nilai rata-rata kecemasan yang diperoleh adalah 16,95 dengan skor kecemasan terendah adalah 10 atau tidak cemas dan tertinggi adalah 25 atau kecemasan sedang. Hasil analisis bivariat menunjukkan bahwa p-value=0,005. Simpulan, hipnosis lima jari kombinasi instrumen musik pop efektif untuk menurunkan kecemasan pada wanita produktif dimasa pandemi COVID-19 di Desa Bengkala, Kabupaten Buleleng Bali.
\end{abstract}

Kata Kunci: Hipnosis Lima Jari, Musik Pop, Wanita

\section{ABSTRACT}

This study aims to determine differences in anxiety among productive women during the COVID-19 pandemic before and after being given five-finger hypnosis with a combination of pop music instruments in Bengkala Village, Buleleng Regency, Bali. This research method is quantitative research with a pre-experimental design, one group pre-post test design. In the univariate analysis of 20 respondents before being given intervention, the average anxiety score obtained was 20.85, with the lowest anxiety score, 15 or mild anxiety, and the highest score was 27 or moderate pressure. After being given the intervention, the average anxiety score obtained was 16.95, with the lowest anxiety score was ten or not anxious, and the highest was 25 or moderate anxiety. The results of the bivariate analysis showed that $p$-value $=0.005$. In conclusion, the five finger hypnosis combination of pop music instruments effectively reduces pressure in productive women during the COVID-19 pandemic in Bengkala Village, Buleleng Regency, Bali.

Keywords: Five Finger Hypnosis, Pop Music, Women 


\section{PENDAHULUAN}

Awal tahun 2020 menjadi tahun yang menggemparkan bagi semua orang diseluruh dunia karena adanya fenomena pandemi Virus Corona (Covid-19) yang membuat kepanikan dimana-mana. Data dari World Health Organizaton (2020) menunjukkan bahwa sebanyak 106 Negara di dunia terpapar virus corona dengan jumlah kasus yang terkonfirmasi 2.804.796 jiwa, dan sebanyak 193.710 jiwa meninggal disebabkan oleh virus Corona. Tidak terkecuali Indonesia juga menjadi salah satu negara yang merasakan dampak dari penyebaran virus Corona ini.

Covid-19 merupakan jenis virus baru yang ditemukan pada tahun 2019 dan belum diidentifikasi menyerang manusia sebelumnya (Zulva, 2020). Covid-19 merupakan penyakit menular yang disebabkan oleh sindrom pernapasan akut coronavirus 2 (severe acute respiratory syndrome coronavirus 2 atau SARS-CoV02) (Setiawan, 2020). WHO menetapkan virus Corona sebagai pandemi pada 11 maret 2020 karena penularan virus ini sangat cepat (Moana, 2020). Status pandemi atau epidemi global menandakan bahwa penyebaran Covid-19 berlangsung sangat cepat.

Permasalahan yang muncul adalah masalah-masalah yang berkaitan dengan aspek kehidupan manusia. Dampak secara psikologis yang muncul adalah kecemasan. Beberapa penelitian menunjukkan bahwa kecemasan merupakan dampak yang ditimbulkan dari kejadian pandemi saat ini. Kecemasan ini memberikan efek melalui perubahan pikiran sehingga menurunkan imunitas tubuh. Hasil penelitian yang dilakukan oleh Ilpaj \& Nurwati (2020) menyatakan bahwa pandemi ini menyebabkan gejala fisik. Tidak hanya fisik, muncul pula gejala psikologis seperti: kecemasan, perasaan takut, perubahan pada pola tidur, stress karena terlalu lama berdiam diri di rumah.

Ada berbagai faktor yang mempengaruhi kecemasan seseorang dimasa pandemi saat ini.Menurut penelitian, kecemasan terhadap COVID-19 dipengaruhi oleh pengetahuan yang kurang tentang COVID-19, perilaku hidup bersih dan sehat yang kurang optimal, kurangnya kemampuan adaptasi terhadap lingkungan dan perubahan besar yang terjadi secara mendadak.Selain itu, juga dipengaruhi oleh faktor pengetahuan tentang kesehatan mental dan fisik, kurangnya keterampilan dalam melakukan deteksi dini kesehatan mental secara individu, dan juga karena faktor koping psikologis yang masih rendah (Zhang et al., 2020).

Situasi ini harus mendapatkan perhatian yang serius. Hal ini untuk menghindari trauma yang nantinya terjadi. Menurut penelitian yang dilakukan Holmes et al., (2020) menyatakan bahwa efek yang muncul karena trauma yang tidak diatasi dengan pemilihan strategi koping yang tepat akan berdampak pada kejadian depresi serta bahaya yang lainnya seperti risiko bunuh diri. Dengan demikian, diperlukan suatu intervensi yang berbasis psikologis untuk menurunkan kecemasan tersebut. Menurut Marbun et al., (2019) menyatakan bahwa ada berbagai terapi non farmakologi yang dapat digunakan untuk menurunkan kecemasan. Terapi yang dapat digunakan adalah terapi yang digunakan adalah psikoterapi, seperti: Relaksasi nafas dalam, Hipnosis lima jari, Relaksasi tot progresif dan Penghentian pikiran.

Penggunaan teknik hipnosis lima jari sebagai terapi hipnoterapi merupakan salah satu alternatif solusi yang bisa digunakan dalam terapi untuk kecemasan. Hipnoterapi dapat memberikan efek relaksasi secara fisik dan secara psikologis. Secara psikologis, hasil penelitian yang dilakukan oleh Sartono et al., (2020) menunjukkan bahwa bahwa penggunaan hipnoterapi memberikan efek percaya diri, memberikan efek relaksasi, 
memberikan ketenangan dalam mengontrol emosi, serta mengubah perspektif seseorang terhadap kecemasan.

Berdasarkan survei awal yang dilakukan peneliti melalui wawancara di Desa Bengkala, Kabupaten Buleleng pada bulan Juli 2020, lima orang responden menyatakan cemas dengan situasi yang terjadi. Semua responden belum pernah diukur kecemasan sebelumnya dan belum mengetahui tentang hipnosis lima jari. Kelebihan penelitian ini adalah masih terbatas penelitian yang menggunakan hipnosis lima jari pada wanita produktif. Selain itu, penelitian ini juga menggunakan kombinasi audio musik pop yang dibuat sendiri oleh peneliti. Berdasarkan uraian di atas, maka tujuan yang hendak dicapai pada penelitian ini adalah untuk mengetahui pengaruh hipnosis lima jari kombinasi instrumen musik pop terhadap kecemasan pada wanita produktif di Desa Bengkala, Kabupaten Buleleng Bali.

\section{METODE PENELITIAN}

Desain penelitian ini adalah penelitian kuantitatif dengan menggunakan rancangan pra eksperimental, one grup pre-post test design. Pemilihan sampel dilakukan dengan menggunakan kuota sampel, dengan jumlah sampel yang digunakan dalam penelitian ini adalah 20 Responden. Sampel dalam penelitian ini adalah kelompok wanita yang ada di Desa Bengkala, Kabupaten Buleleng, Bali. Adapun kriteria inklusi dalam penelitian ini adalah responden yang menandatangani inform concent, masih produktif, serta mengikuti sampai akhir proses penelitian.

Pelaksanaan penelitian ini dilakukan di Desa Bengkala, Kabupaten Buleleng. Periode penelitian dilaksanakan pada bulan Juli - September 2020. Alat ukur yang digunakan untuk mengukur kecemasan Responden adalah dengan menggunakan kuesioner Hamilton Rating Scale For Anxiety (HARS). Rentang kecemasan dibagi menjadi lima skor kecemasan yaitu tidak cemas (Skor 0-13), cemas ringan (Skor 14-20), cemas sedang (Skor 21-27), cemas berat (Skor 28-41) dan cemas sangat berat (Skor 4256). Kuesioner ini merupakan kuesioner yang telah baku untuk mengukur Kecemasan. Pengukuran dilakukan sebanyak dua kali, yaitu sebelum diberikan intervensi dan setelah diberikan intervensi. Intervensi dilakukan selama dua minggu dengan pemberian intervensi dua kali dalam seminggu.

Setelah data terkumpul, kemudian dilakukan proses pengolahan data. Hasil pengujian terhadap normalitas data diperoleh bahwa data berdistribusi normal sehingga menggunkaan statistik parametrik dengan menggunakan paired $t$-test untuk mendapatkan $p$-value nya.

\section{HASIL PENELITIAN}

Analisis Univariat

Tabel. 1

Karakteristik Responden Berdasarkan Umur

\begin{tabular}{cccccc}
\hline $\mathrm{N}$ & Min & Maks & Mean & SD & $95 \%$ CI \\
\hline 20 & 35 & 55 & 44,5 & 6,345 & $41,58-47,52$ \\
\hline
\end{tabular}

Berdasarkan tabel 1 dapat dilihat bahwa rata-rata umur dari 20 responden penelitian ini adalah 44,5 tahun dengan standar deviasi 6,345. 
Tabel. 2

Karakteristik Responden

Berdasarkan Pekerjaan

\begin{tabular}{|c|c|c|}
\hline Pekerjaan & Jumlah & Persentase \\
\hline Ibu Rumah Tangga & 2 & $10 \%$ \\
\hline Pedagang & 9 & $45 \%$ \\
\hline Petani & 9 & $45 \%$ \\
\hline Total & 20 & $100 \%$ \\
\hline
\end{tabular}

Berdasarkan tabel 2 dapat dilihat bahwa dari 20 responden, hanya $10 \%$ yang bekerja sebagai ibu rumah tangga. Kegiatan yang dilakukan selain sebagai ibu rumah tangga adalah sebagai pembuat jamu, sehingga dimasukkan ke dalam kelompok produktif.

Tabel. 3

Kecemasan Sebelum

Diberikan Intervensi

\begin{tabular}{cccccc}
\hline $\mathrm{N}$ & Min & Maks & Mean & SD & $95 \%$ CI \\
\hline 20 & 15 & 27 & 20,85 & 3,829 & $19,06-22,64$ \\
\hline
\end{tabular}

Berdasarkan tabel 3 dapat dilihat bahwa rata-rata kecemasan dari 20 responden penelitian ini adalah pada skor 20,85 dengan standar deviasi sebesar 3,829.

Tabel. 4

Kecemasan Setelah

Diberikan Intervensi

\begin{tabular}{cccccc}
\hline $\mathrm{N}$ & Min & Maks & Mean & SD & $95 \%$ CI \\
\hline 20 & 10 & 25 & 16,95 & 3,993 & $15,08-18,82$ \\
\hline
\end{tabular}

Berdasarkan tabel 4 dapat dilihat bahwa rata-rata kecemasan dari 20 responden setelah diberikan intervensi adalah pada skor 16,95dengan standar deviasi sebesar 3,993 .

\section{Analisis Bivariat}

Tabel. 5

Distribusi Rata-Rata Kecemasan Responden Pengukuran 1 dan Pengukuran 2

\begin{tabular}{lccccc}
\hline \multicolumn{1}{c}{ Variabel } & Mean & SD & SE & P value & N \\
\hline Kecemasan & & & & & \\
Pengukuran 1 & 20,85 & 3,829 & 0,856 & 0.005 & 20 \\
Pengukuran 2 & 16,95 & 3,993 & 0,893 & & \\
\hline
\end{tabular}

Berdasarkan tabel 5 didapatkan nilai p 0,005, sehingga terdapat perbedaan yang signifikan antara skor kecemasan pada pengukuran pertama dengan skor kecemasan pada pengukuran kedua. 


\section{PEMBAHASAN}

Berdasarkan tabel 1 menunjukkan karakteristik responden berdasarkan umur. Rata-rata umur responden adalah 44,5 tahun. Kategori umur ini merupakan kelompok usia produktif bila dikatagorikan menurut World Health Organization (WHO). Pada usia produktif, maka hal yang paling penting dilakukan pada masa pandemi adalah dengan menjaga pola hidup bersih dan sehat. Hal ini sangat penting karena usia produktif harus memiliki kondisi tubuh yang bugar sehingga bisa beraktifitas dengan baik. Ketahanan ini juga sangat penting untuk persiapan nanti setelah memasuki usia tua. Semakin dewasa umur, tentu banyak masalah kesehatan yang akan muncul, baik itu masalah secara fisik, psikologis, serta masalah-masalah sosial. Hasil Penelitian ini sejalan dengan dengan teori perkembangan manusia.

Berdasarkan tabel 2 menunjukkan karakteristik responden berdasarkan pekerjaan. Semua usia produktif pasti memiliki pekerjaan tetap. Ini dilakukan untuk proses bertahan hidup serta untuk memperoleh penghasilan. Secara geografis letak desa Bengkala berada dekat dengan dataran rendah, sehingga aktifitas masyarakat cenderung sebagai petani, peternak, dan adapula yang berdagang. Selain itu, beberapa masyarakat juga mencoba membuat jamu sebagai usaha di dalam rumah tangga.

Berdasarkan tabel 3 menunjukkan skor kecemasan sebelum diberikan intervensi. Dari tabel tersebut, diketahui bahwa rata-rata skor kecemasannya adalah 20,85. Ada banyak alat ukur yang bisa digunakan untuk menilai kecemasan seseorang. Selama pandemi trend kecemasan mengalami peningkatan yang sangat signifikan. Perhatian khusus perlu diberikan kepada perempuan untuk mengelola kecemasan, karena pada umumnya, perempuan lebih sensitif terhadap perasaan cemas. Inilah yang menjadikan COVID-19 memberikan dampak secara psikologis hingga muncul kecemasan. Pandemi ini merupakan stressor yang bisa berdampak sangat berat. Karena perbedaan kemampuan seseorang dalam beradaptasi dengan situasi saat ini.

Kecemasan setiap orang tentunya berbeda-beda, hal ini dipengaruhi oleh berbagai faktor. Hasil penelitian yang dilakukan oleh Gumantan et al., (2020) menunjukkan bahwa tingkat kecemasan seorang terhadap COVID-19masih sangat besar. Faktor yang menyebabkan antara lain penerapan new normal, jenis kelamin, serta berusia produktif. Kecemasan yang timbul akibat penerapan new normal berasal dari perbedaan kebijakan antar daerah tentang penerapan new normal tersebut. Menurut jenis kelamin, perempuan lebih banyak dan lebih mudah mengalami kecemasan. Usia produktif juga menjadi faktor penyebab kecemasan karena munculnya kekhawatiran bahwa COVID-19bisa menjadi pemicu komplikasi penyakit lain di dalam tubuh. Selain itu, menurut Zhang et al., (2020) menyatakan bahwa faktor-faktor kecemasan yang terjadi bisa juga karena pengetahuan tentang kesehatan mental dan fisik, kurangnya keterampilan dalam melakukan deteksi dini kesehatan mental secara individu, dan juga karena faktor koping psikologis yang masih rendah.

Berdasarkan tabel 4 menunjukkan rata-rata kecemasan setelah diberikan hipnosis lima jari kombinasi instrumen musik pop. Rata-rata Kecemasan dari 20 responden setelah diberikan intervensi adalah pada skor 16,95. Skor kecemasan terendah adalah 10 dan skor kecemasan tertinggi adalah 25 , dengan standar deviasi sebesar 3,993. Hasil tersebut menunjukkan Adanya penurunan terhadap kecemasan setelah diberikan hipnosis lima jari. Penggunaan teknik hipnosis lima jari kombinasi instrumen musik pop memberikan efek relaksasi pada responden. Hal ini termasuk dalam promosi kesehatan. Promosi kesehatan mental mengenai cara menurunkan kecemasan juga penting diberikan, salah satunya dengan hipnoterapi. 
Penelitian yang sejalan dengan penelitian ini adalah penggunaan hipnoterapi yang dilakukan oleh Daryanti \& Mardiana (2020) hasil penelitiannya menemukan bahwa sebelum diberikan hipnoterapi, tingkat kecemasan pasien pre operasi ada pada kategori tingkat kecemasan berat. Setelah diberikan hipnoterapi, tingkat kecemasan pasien ada pada kategori kecemasan sedang. Dengan demikian, penggunaan hipnoterapi terbukti efektif untuk menurunkan tingkat kecemasan pada pasien pre operasi hernia di RS TNI AU dr. M Salamun Bandung tahun 2019.

Hasil penelitian Winarsih \& Rohmadani (2020) menjelaskan bahwa Islami hipnoterapi dapat mengurangi kecemasan orang tua terhadap masa depan anak yang mengalami gangguan spektrum autisme. Tingkat kecemasan orang tua berkurang setelah mengikuti hipnoterapi Islam. Subjek penelitian juga melaporkan munculnya emosi dan pikiran positif setelah mengikuti seluruh sesi hipnoterapi Islami, seperti merasa lebih tenang, lega, ikhlas, kurang berpikiran negatif, lebih optimis, lebih percaya diri, dan mudah mengendalikan emosi saat marah. Pasalnya, dalam hipnoterapi Islam terdapat mekanisme sugesti, imagery, relaksasi, restrukturisasi kognitif, dan submission untuk menurunkan tingkat kecemasan.

\section{Pembahasan Analisis Bivariat}

Berdasarkan tabel 5 Rata-rata skor kecemasan pada pengukuran pertama kecemasan adalah 20,85 dengan standar deviasi 3,829. Pada pengukuran kedua didapatkan rata-rata skor kecemasan adalah 16.95 dengan standar deviasi 3,993. Terlihat nilai rata-rata perbedaan pengukuran pertama dan pengukuran kedua adalah 3.9 (mengalami penurunan skor kecemasan) dengan standar deviasi 2,150. Hasil uji statistik didapatkan nilai 0,005 , maka disimpulkan terdapat perbedaan yang signifikan antara skor kecemasan pada pengukuran pertama dengan skor kecemasan pada pengukuran kedua.

Penelitian yang telah dilakukan menunjukkan bahwa secara kuantitatif, penggunaan hipnosis lima jari kombinasi musik pop efektif untuk menurunkan kecemasan pada wanita produktif di desa Bengkala, Kabupaten Buleleng Bali. Hal ini disebabkan karena efek relaksasi dari mendengarkan Instrumen musik dikombinasikan dengan Hipnosis Lima Jari membuat situasi menjadi tenang dan memberikan rasa percaya diri pada responden.

Hasil penelitian ini sejalan dengan penelitian yang dilakukan oleh Marbun et al., (2019) dengan memberikan hipnosis lima jari pada ibu hamil menjelang persalinannya. Hasil penelitiannya menunjukkan bahwa selisih perbedaan nilai sebelum dan sesudah diberikan terapi hipnotis lima jari, dimana sebelum diberikan terapi hipnotis lima jari tingkat kecemasan ibupre partum didapatkan nilai 21-34 yaitu berada diantara kecemasan sedang dan berat, sedangkan sesudah diberikan terapi hipnotis lima jari tingkat kecemasan ibu pre partum didapatkan nilai 7-20 yaitu berada diantara tidak ada kecemasan dan kecemasan ringan. Hal ini berarti terdapat efektivitas hipnotis lima jari terhadap tingkat kecemasan pada ibu pre partum.

\section{SIMPULAN}

Nilai rata-rata kecemasan mengalami penurunan setelah diberikan intervensi. Pemberian hipnosis lima jari kombinasi musik pop berpengaruh signifikan terhadap kecemasan wanita produktif di Desa Bengkala, Kabupaten Buleleng Bali. 


\section{SARAN}

Hasil penelitian ini diharapkan dapat dijadikan acuan dalam pengembangan model intervensi keperawatan, khususnya yang berhubungan dengan terapi-terapi kesehatan mental untuk menurunkan kecemasan dimasa pandemi COVID-19. Kepada pihak Desa Bengkala, Kabupaten Buleleng Bali agar dapat selalu menerapkan teknik Hipnosis Lima Jari Kombinasi Instrumen Musik Pop secara rutin untuk menurunkan kecemasan dimasa pandemi. Penelitian lain bisa mengacu pada penelitian ini dengan menambahkan kearifan lokal dan juga pengembangan model-model lain hipnoterapi untuk relaksasi dimasa pandemi.

\section{DAFTAR PUSTAKA}

Daryanti, E., \& Mardiana, F. (2020). Efektifitas Hypnotherapy dalam Mengurangi Tingkat Kecemasan Pasien Preoperasi Hernia di RS TNI AU dr. M Salamun Bandung. Jurnal Keperawatan dan Kebidanan, 4(1), 24-33. http://jmkubk.id/index.php/jmk_kb/article/view/97/89

Gumantan, A., Mahfud, I., \& Yuliandra, R. (2020). Tingkat Kecemasan Seseorang Terhadap Pemberlakuan New Normal dan Pengetahuan terhadap Imunitas Tubuh. Sport Science \& Education Journal Volume, 1(2), 18-27. DOI: https://doi.org/10.33365/ssej.v1i2.718

Holmes, E. A., Connor, R. C. O., Perry, V. H., Tracey, I., Wessely, S., Arseneault, L., Ballard, C., Christensen, H., Silver, R. C., Everall, I., Ford, T., John, A., Kabir, T., King, K., Madan, I., Michie, S., Przybylski, A. K., Shafran, R., Sweeney, A., \& Bullmore, E. (2020). Position Paper Multidisciplinary Research Priorities for the COVID-19 Pandemic : A Call for Action for Mental Health Science. The Lancet Psychiatry, 366(20), 1-14. https://doi.org/10.1016/S2215-0366(20)30168-1

Ilpaj, S. M., \& Nurwati, N. (2020). Analisis Pengaruh Tingkat Kematian Akibat Covid19 terhadap Kesehatan Mental Masyarakat Indonesia. Focus: Jurnal Pekerjaan Sosial, 3(1), 16-28. DOI: 10.24198/focus.v3i1.28123

Marbun, A. S., Pardede, J. A., \& Perkasa, S. I. (2019). Efektifitas Terapi Hipnotis Lima Jari Terhadap Kecemasan Ibu Pre Partum di Klinik Chelsea Husada Tanjung Beringin Kabupaten Serdang Bedagai. Jurnal Keperawatan Priority, 2(2), 92-99. https://doi.org/10.34012/jukep.v2i2.568

Moana, N. (2020). Konsep Isolasi dalam Jaringan Sosial untuk Meminimalisasi Efek Contagious (Kasus Penyebaran Virus Corona di Indonesia). Jurnal Sosial Humaniora Terapan, 2(2), 11-12. http://journal.vokasi.ui.ac.id/index.php/jsht/article/view/86

Sartono, S., Suryaman, O., Hadiana, O., \& Ramadan, G. (2020). Hipnoterapi untuk Kecemasan: Sebuah Uji Coba pada Pemain Sepakbola Hipnoterapy for Anxiety: A Trial Test on Football Players. Jurnal SPORTIF: Jurnal Penelitian Pembelajaran, 6(1), 216-225. https://doi.org/10.29407/js_unpgri.v6i1.13832

Setiawan, A. R. (2020). Lembar Kegiatan Literasi Saintifik untuk Pembelajaran Jarak Jauh Topik Penyakit Coronavirus 2019 (COVID-19). Edukatif: Jurnal Ilmu Pendidikan, 2(1), 28-37. DOI: 10.31004/edukatif.v2i1.80

Winarsih, T., \& Rohmadani, Z. V. (2020). Islamic Hypnotherapy to Reduce Parent Anxiety Towards the Future of Children with Autistic. Al-Balagh: Jurnal Dakwah dan Komunikasi, 5(1), 1-26. https://doi.org/10.22515/al-balagh.v5i1.1953 
World Health Organizaton. (2020). Clinical Management of Severe Acute Respiratory Infecton when Novel Coronavirus (nCoV) Infecton is Suspected. Geneva: World Health Organizaton. https://www.who.int/publications-detail-redirect/clinicalmanagement-of-covid-19

Zhang, J., Wu, W., Zhao, X., \& Zhang, W. (2020). Recommended Psychological Crisis Intervention Response to the 2019 Novel Coronavirus Pneumonia Outbreak in China: a Model of West China Hospital. Precision Clinical Medicine, 3(February), 3-8. https://doi.org/10.1093/pcmedi/pbaa006

Zulva, T. N. I. (2020). Covid-19 Dan Kecenderungan Psikosomatis. Journal of Chemical Information and Modeling, 53(9), 1-4. academia.edu 